\title{
Развитие Ярославля во II половине XIX - начале XX века
}

\author{
М.В.Нащокина, НИИТИАГ, Москва
}

Статья посвящена обзору градостроительных изменений и проектных инициатив во всех сферах городской жизни в Ярославле второй половины XIX - начала XX века и базируется на архивных документах. Ярославль, возникновение которого связано с именем Ярослава Мудрого, - крупный губернский город, расположенный на высоком мысу при впадении реки Которосли в Волгу, к середине XIX века имел уже более чем восьмивековой возраст. Как и в большинстве волжских городов, основным градоформирующим фактором в Ярославле второй половины XIX - начала XX века было развитие порта и связанных с ним подъездных путей (включая стремительно умножавшиеся железные дороги), складских территорий, мостов, портовых инженерных сооружений, и развитие промышленности, иногда впрямую, иногда опосредованно также связанной с жизнью порта, от которого, как правило, зависел ввоз сырья и вывоз готовой продукции. Исследование показало, что сложившаяся градостроительная структура Ярославля не подвергалась в этот период серьёзным реконструктивным переменам, коррективы чаще всего обслуживали насущные потребности. Осуществление проектов, рассчитанных на далёкую перспективу (проект зимней гавани в устье Которосли), наталкивалось на экономические препятствия и частнособственнические интересы, шедшие в разрез с интересами города в целом. Таким образом, отличительной чертой градостроительного развития Ярославля второй половины XIX - начала XX века был последовательный традиционализм в сфере архитектурного образа и стилистики в сочетании с внедрением в городское благоустройство многих технических новаций, развитием железнодорожного строительства и портового хозяйства.

Ключевые слова: градостроительство Ярославля второй половины XIX - начала XX века, общественные здания, развитие портовых функций, развитие железнодорожного и речного транспорта, традиционные черты в градостроительстве, регулярный план, ансамбли центра Ярославля, неоклассицизм начала XX века, иноверческие храмы, инженер П.П. Чубинский.

\section{The Development of Yaroslavl in the Second Half of XIX - Early XX Century}

\section{M.V.Nashhokina, NIITIAG, Moscow}

The article provides an overview of urban change and project initiatives in all spheres of urban life in Yaroslavl in the second half of the XIX - beginning of XX century and is based on archival documents. Yaroslavl is alarge governorate city located on a high cape at the confluence of the Kotorosli river in the Volga, the emergence of which is associated with the name of Yaroslav the Wise, by the middle of the XIX century it was more than eight centuries old. As in most of the Volga cities, the main town-forming factor in Yaroslavl in the second half of the XIX - early XX century was the development of the port and associated access roads (including rapidly multiplying railways), warehouse areas, bridges, port engineering facilities, and the development of industry, sometimes directly, sometimes indirectly interconnected with the life of the port, which, as a rule, depended on the import of raw materials and export of finished products. The study showed that the current urban structure of Yaroslavl was not subjected to serious reconstructive changes during this period, adjustments often served immediate needs. Implementation of projects designed for the long term (such as winter harbour at the mouth of the Kotoros( river) faced economic obstacles and private property interests that ran counter to the interests of the city as a whole. Thus, a distinctive feature of the urban development of Yaroslavl in this period was consistent traditionalism in the field of architectural image and style, combined with the introduction of urban improvement of many technical innovations, the development of railway construction and port facilities.

Keywords: urban development, Yaroslavl, second half of the XIX - beginning of XX century, public buildings, port functions, rail and river transport, traditional features in urban planning, regular plan, ensembles, the Neoclassicism, heterodox temples, engineer P.P. Chubinsky.

Ярославль, возникновение которого связано с именем Ярослава Мудрого, - крупный губернский город, расположенный на высоком мысу при впадении реки Которосли в Волгу, к середине XIX века имел уже более чем восьмивековой возраст. В 1897 году здесь проживало 71616 человек, то есть по количеству жителей город был одним из крупнейших в России [1, с. 196-197] ${ }^{1}$. Этому, безусловно, способствовало его местоположение, придававшее ему важное торговое значение на протяжении всей российской истории. Благодаря ему один из древнейших центров Руси - Ярославль, несмотря на беды

${ }^{1}$ К сожалению, градостроительное развитие Ярославля оказалось почти не затронуто в книге «Градостроительство России середины XIX - начала XX века». (М., Прогресс-Традиция, 2010). 
средневековых войн и разорений, может быть отнесён к числу наиболее стабильно развивавшихся городов страны. Расположение на берегу великой реки, прихотливые извивы которой вместе с вязью тысяч её притоков объединяют европейскую часть страны в единое целое, обусловило тот факт, что даже после опустошительных пожаров город очень быстро отстраивался и продолжал расти. Эта тенденция сохранилась и после утверждения в 1778 году перепланировочного регулярного плана Ярославля, включившего все средневековые храмы и капитальные постройки, и позднее: в XIX - начале XX века.

Как и в большинстве волжских городов, основным градоформирующим фактором в Ярославле второй половины XIX - начала XX века было развитие порта и связанных с ним подъездных путей (включая стремительно умножавшиеся железные дороги), складских территорий, мостов, портовых инженерных сооружений и развитие промышленности, иногда впрямую, иногда опосредованно также связанной с жизнью порта, от которого, как правило, зависел ввоз сырья и вывоз готовой продукции. Эти два основных фактора в наибольшей степени влияли на изменение планировочной структуры сложившегося города - вокруг портов и крупных промышленных предприятий возникали новые жилые слободы, а в начале XX века - комплексы дешёвых жилищ для рабочих, которые, постепенно благоустраиваясь, обретали необходимые общественные сооружения - школы, церкви, народные дома и т.д.

После принятия к исполнению нового перепланировочного плана Ярославля 1778 года, скорректированного в 1834-м в соответствии с произошедшими в городе изменениями, к середине XIX столетия город обрёл новый облик. В первой половине XIX века регулярный план екатерининского времени был во многом уже воплощён в натуре, что отразили планы середины столетия («План города Ярославля, гравированный со съёмки... при Военно-топографическом депо» в 1846 году и др.) [2, с. 339-350.].

Особенно преобразилась центральная часть города. Здесь была создана серия новых городских ансамблей и новая городская ткань, сочетавшая постройки периода классицизма с древними памятниками. Эти два равнозначных для образа города первой половины XIX века стилистических начала пронизали всю городскую среду, начиная со «Стрелки» - древнего мыса между Волгой и Которослью, где к монументальному объёму пятиглавого средневекового Успенского кафедрального собора, дополненного в середине XIX столетия грузной колокольней, присоединился классицистический блок Демидовского юридического лицея, основанного в 1803 году. В центре города разместились также классицистические здания почтамта, Гостиного двора, Губернаторского дома и т.д. Развитость и полноценное художественное воплощение этих двух стилистических тенденций в архитектуре Ярославля оказали влияние и на формирование его архитектурного облика во второй половине XIX - начале XX века, обеспечив его своеобразие.

В середине XIX столетия ещё продолжалось строительство по утверждённому регулярному плану крупных общественно значимых сооружений. Строились Духовная консистория², Женское епархиальное училище ${ }^{3}$, Духовная семинария ${ }^{4}$, больница 5 и некоторые другие здания. Другими словами, завершалось государственно санкционированное насыщение губернского города общественными зданиями, где сосредотачивались основные управленческие, социальные и духовные службы, и продолжали претворяться в жизнь идеи функционального зонирования, заложенные в структуру города ещё во второй половине XVIII века. Если позднее средневековье сформировало в Ярославле развитую иерархическую структуру храмов, то эпоха классицизма утвердила иерархию зданий

${ }^{2} 0$ постройке Духовной консистории в Ярославле. 1851-1853 // РГИА. Ф. 218. 0п. 4. Е.х. 444.

3 Проект Ярославского епархиального женского училища. 1855. Арх. Н. Попов и Кудинов // РГИА. Ф. 835. 0п. 1. Е х. 1022; Проект церкви при женском епархиальном училище. 1858-1861. Арх. Ф. Солнцев, Н. Попов // РГИА. Ф. 835. 0п. 1. Е.х. 1025.

${ }^{4} 0$ постройке Духовной семинарии в Ярославле. 1857-1859 гг. // РГИА. Ф. 218. 0п. 4. Е.х. 806. Л. 11-20; Проект Ярославской духовной семинарии 1860-1870. Арх. Дорофеевский // РГИА. Ф. 835. 0п. 1. Е.х. 1021.

${ }^{5} 0$ постройке здания больницы в Ярославле. 1853-1856 // РГИА. Ф. 218. 0п. 4. Е.х. 563.

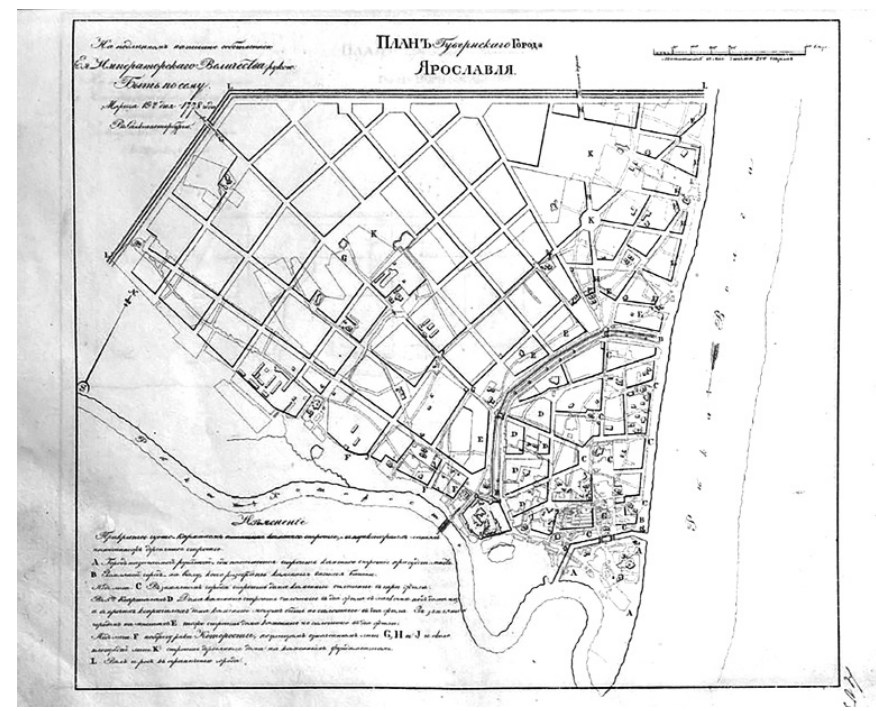

Рис. 1. План Ярославля. 1778 год

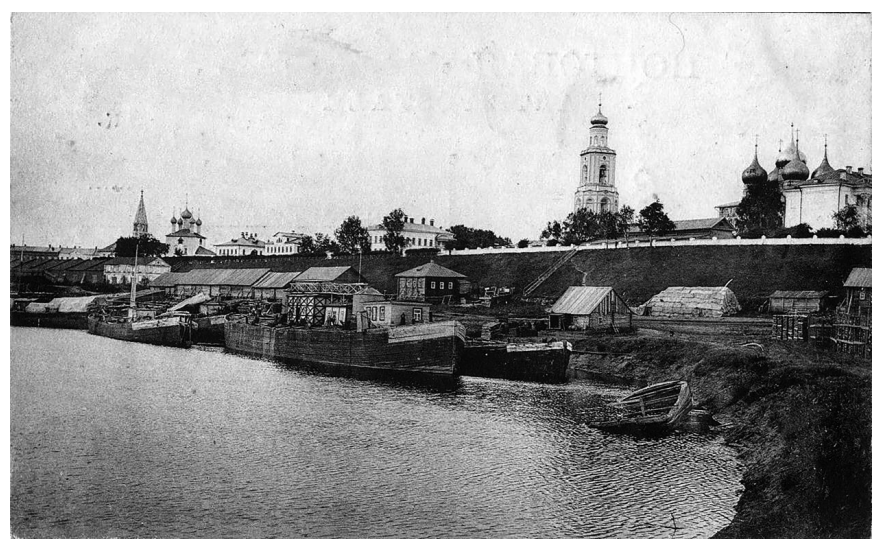

Рис. 2. Вид центра Ярославля со стороны Которосли. Конец XIX века 
для государственных учреждений. На центральной городской площади расположились Губернские присутственные места, Казённая палата, губернская гимназия. За рекой Которослью разместился огромный комплекс казарм военных кантонистов 3-го карабинерного полка, заводы и больница - за чертой жилой постройки.

В основных чертах тенденция к традиционной иерархичности сохранялась и во второй половине XIX века, хотя её соблюдение становилось всё менее жёстким - в городскую ткань неизбежно вторгались новые градостроительные элементы: ветки железных дорог, вокзал, новые пристани, ломавшие сложившееся иерархическое единство постройки и выстраивавшие новые визуальные и транспортные связи. Если новое общественное управление городом - Городская дума ${ }^{6}$ в середине $1870-x$ годов вошла в комплекс зданий центральной площади, уменьшение роли армии в жизни общества, демократизация жизни выразились в том, что в комплексе бывших казарм на Большой Московской улице поместилась Военная прогимназия. В соответствии со строительным законодательством за чертой застройки был выстроен пиво-медоваренный завод «Северная Бавария».

Однако в 1860-х - первой половине $1870-x$ годов планировочные и функциональные изменения в городе касались лишь отдельных фрагментов застройки. Так, в 1867 году был разработан проект регулирования Власьевской площади ${ }^{7}$, в в 1872-м под жилую застройку решено было обратить обширную территорию площади, по плану 1778 года предназначенной для торговли лесом ${ }^{8}$. Важной вехой в процессе формирования новой планировочной структуры Ярославля стал 1877 год. Стихийный рост города в юго-западном направлении заставил в этом году поставить вопрос перед Министерством внутренних дел об утверждении нового проектного плана, где планировочные изменения вносились именно в эту часть города ${ }^{9}$. Этот план был утверждён в 1884-м. Однако и он не смог учесть всех изменений, которые вносила в городскую ткань быстро менявшаяся жизнь, поэтому дополнительные коррективы вносились в план города довольно часто, фактически каждые два-три года в $1891-\mathrm{M}^{10}$, в $1893-\mathrm{M}^{11}$, в $1896-\mathrm{M}^{12}$, в $1898-\mathrm{M}^{13}$ и позже.
Характерным примером локальных изменений городского плана в конце XIX века может служить подбор и перепланировка места для размещения электрической станции, вагонного сарая и здания управления в 1898 году. Интересно, что, несмотря на свои, в основном, согласующие функции, Техническо-строительный комитет МВД не сразу согласился с мнением Губернского правления о размещении новых построек близ Воскресенской церкви. Городским властям пришлось аргументированно настаивать, и лишь после этого ТСК утвердил это решение ${ }^{14}$, вытекавшее из насущных городских нужд.

Происходившие в застройке перемены, менявшие генеральный план города, не случайно коснулись именно юго-западной части, расположенной за рекой Которослью. С этой стороны к городу подходили две важные дороги, издревле связывавшие город с центром России - на Москву и на Суздаль. Именно в этой части города рядом с Бутырской слободой сосредоточилось в конце XIX века и железнодорожное строительство. Здесь прошла железная дорога, соединившая город с соседними поволжскими городами - Костромой и Рыбинском, здесь появился вокзал, сюда же подошла и железная дорога из Москвы, дошедшая позднее до Архангельска, здесь же на Которосли решено было построить хорошо оборудованную зимнюю гавань. Совокупность этих факторов обусловила преимущественный рост города именно в этом направлении.

Весьма актуальным в связи с этим было создание постоянных связей между Заречьем и собственно городом. С середины XIX века через Которосль проектируются мосты так называемой «американской системы», сначала деревянные, потом металлический, который сменяет в конце столетия основной деревянный ${ }^{15}$. Постоянной была забота города о пристанях: торговых ${ }^{16}$ и пассажирских на Волге, грузовых на Которосли, а также набережных, особенно прогулочной - Волжской ${ }^{17} \mathrm{c}$ нарядной шестиколонной беседкой - бельведером, откуда открывался вид на заволжские дали, деревни Тверицы, Рогово и Новотроицкую слободу. Заметим, что отсутствие постоянного моста через Волгу во второй половине XIX - начале XX века, который бы обеспечил связь города с Заволжьем, и размещение всех основных путей сообщения - железных дорог и пристаней

\footnotetext{
${ }^{6}$ См.: 0 преобразовании городского общественного управления в г. Ярославле (проект) 1863 // РГИА. Ф. 1287. 0п. 37. Е.х. 2192; 0 закрытии Ярославского городового магистрата. 1865-1866 // РГИА. Ф. 1405. 0п. 63. Е.х. 4984.

${ }^{7} 0$ плане на регулирование Власьевской площади г. Ярославля // 1867 г.РГИА. Ф. 1287. 0п. 40. Е.х. 167.

${ }^{8} 0 б$ обращении под застройку площади в г. Ярославле, назначенной по плану для лесной торговли. 1872-1888 // РГИА. Ф. 1287.0 п. 4. Е.х. 1085.

${ }_{9}^{9} 0$ новом проектном плане на урегулирование города Ярославля. 1877-1884 гг.// РГИА. Ф. 1293. 0п. 113. Е.х. 158. Л. 8.

${ }^{10} 06$ изменении части плана г. Ярославля в связи с застройкой. 1891 // РГИА. Ф. 1293. 0п. 124. Е.х. 96.

${ }^{11} 06$ изменении части плана г. Ярославля. 1893-1900 // РГИА. Ф. 1297. 0п. 41. Е.х. 313.

1206 изменении части плана г. Ярославля в связи с постройкой Знаменской часовни. 1896 // РГИА. Ф. 1293. 0п. 129. Е.х. 221.

${ }^{13} 06$ изменении части плана г. Ярославля с постройкой на Семёновской площади гимназии. 1893-1900 // РГИА. Ф. 1293. 0п. 131. Е.х. 177. Л. 3-4.

${ }^{14} 06$ изменении части плана г. Ярославля в связи с постройкой электрической станции... 1898 // РИА. Ф. 1293. 0п. 131. Е.х. 177. Л. 3-4.

${ }^{15}$ Планы мостов через р. Которосль в г. Ярославле. Сер. ХІХ в. // РГИА. Ф. 1293. 0п. 168, Яросл. Губ.. Е.х. 44, 45, 46; Ф. 176. 0п. 1. Кн. 2. Е.х. 2326; 0 постройке железного моста через Которосль в Ярославле взамен существующего деревянного американской системы. 1874-1878 // РГИА. Ф. 176. 0п. 1. Е.х. 1297; 0 постройке американского моста на р. Которосли. 1899 // РГИА. Ф. 190. Оп. 4. Ч. 1. Е.х. 1000.

${ }^{16} 0 б$ устройстве для постоянной торговли пристани на берегу р. Волги. 1873-1874 // РГИА. Ф. 176. 0п. 1. Е.х. 1297.

${ }^{17}$ По рапорту Ярославского губернатора об изменении городской думой проекта устройства Волжской набережной в Ярославле. 1874 // РГИА. Ф. 1341.0 п. 133. E.x. 528.
} 

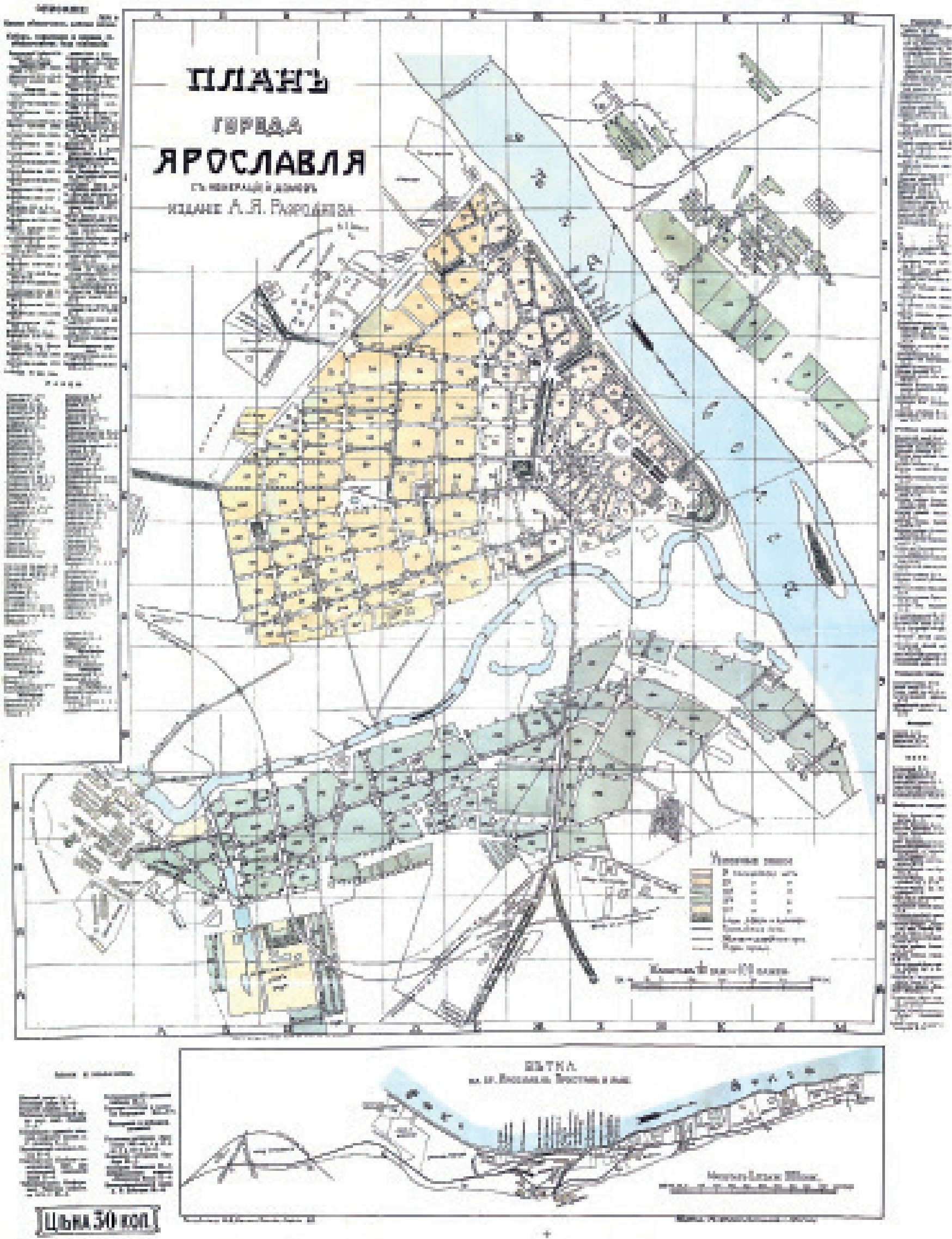

Рис. 3. План Ярославля. 1911 год 
- на правом берегу реки не способствовали промышленному и градостроительному развитию левобережных заволжских поселений как полноценных частей Ярославля, то есть городская территория не распространялась на противоположный берег. Лишь в 1900-х годах началось проектирование и устройство железнодорожной переправы через Волгу ${ }^{18}$, а в конце 1900-х был построен гигантский пятипролётный железнодорожный мост выше города по течению реки.

Главным для Ярославля второй половины XIX века было развитие портового хозяйства и благоустройство гавани, которая могла бы облегчить процесс разгрузки и погрузки сырья и товаров и обеспечить безопасную зимовку судов между навигациями. Это сулило городу немалые прибыли как за аренду зимовочных мест, так и за использование складских территорий. Проект гавани был разработан инженером П.П. Чубинским в 1898-1899 годах [3], однако сложность и дороговизна строительства растянула обсуждение на первые десятилетия XX века и в конечном счёте не позволила его осуществить.

В чём же состояла идея? Анализируя портовую ситуацию в Ярославле, Чубинский писал, что берега Которосли и её устье использовались до сих пор не очень эффективно. В период навигации река и её пологие берега служат, главным образом, для выгрузки леса [3, с. 11]. На Волге в окрестностях Ярославля отсутствуют затоны, и потому, несмотря на то, что устье Которосли в качестве затона весьма ненадёжно, после закрытия навигации его восточная часть обычно сплошь загромождена судами до Американского моста (этот металлический мост в конце XIX века соединил Заречье - район за Которослью, с основной частью города). Автор проекта, поддержанного в 1899 году Городской Думой ${ }^{19}$, считал, что устье необходимо расширить и углубить, отделив его от Волги мощной дамбой. Для разгрузки же товаров необходимо устроить дальше за Американским мостом ${ }^{20}$, который требует в этом случае перестройки в разводной, несколько карманов-каналов, к которым будут непосредственно подведены железнодорожные пути. Несмотря на то, что проект рационально решал действительно насущные проблемы Ярославского порта, осуществление его требовало слишком больших затрат.

Вплоть до 1903 года вопрос по созданию гавани был открыт, так как управление Московско-Ярославской железной дороги не давало заключения относительно предложенного местоположения железнодорожных пристаней. Город тем временем предполагал выпустить облигационный заём на начало производства работ ${ }^{21}$, требующих очень крупных вложений. Последовавший через некоторое время фактический отказ дороги участвовать в сооружении гавани, вызванный скорее всего её собственными финансовыми трудностями, подвёл черту под реализацией проекта П.П. Чубинского. Управление Московско-Ярославской железной дорогой сообщило, что создание благоустроенных пристаней и гавани в Ярославле мало затрагивает её интересы, поэтому оно не собирается принимать участие ни в дальнейшей разработке проекта, ни в расходах на сооружение. Другим негативным фактором, не позволившим начать осуществление строительства гавани, было то, что часть реки Которосли до фабрики товарищества Большой мануфактуры должна была быть изъята из пользования отдельных владельцев складами и пристанями и передана в распоряжение Городского управления. Это наносило экономический ущерб мелким собственникам, которых в этом случае не могли утешить никакие посулы будущего общего благосостояния. Так, по экономическим причинам не получил воплощения в натуре один из незаурядных градостроительных проектов конца XIX века. В менее развёрнутом виде к проекту создания зимней гавани для стоянки судов вернулись вновь лишь в 1913 году, однако осуществлению этого проекта помешала война.

Большинство градостроительных начинаний Ярославской городской думы в 1900-х года, вносивших изменения в планировочную структуру города, носило не столько

${ }_{18} 06$ устройстве затонов для проектируемой железнодорожной переправы через р. Волгу в Ярославле. 1907. // РГИА. Ф. 190. Оп. 4. Ч. 1. Е.х. 1277.

${ }^{19}$ Дело о разрешении г. Ярославлю выпуска облигаций на 1175000 руб. для устройства гавани на реке Которосли у города Ярославля 1900-1907 // РГИА. Ф. 1287. 0п. 30. Е.х. 2036. Л. 105.

${ }^{20} 0$ постройке американского моста на р. Которосли. 1899 // РГИА. Ф. 190. Оп. 4. Ч. 1. Е.х. 1000.

${ }^{21}$ Там же

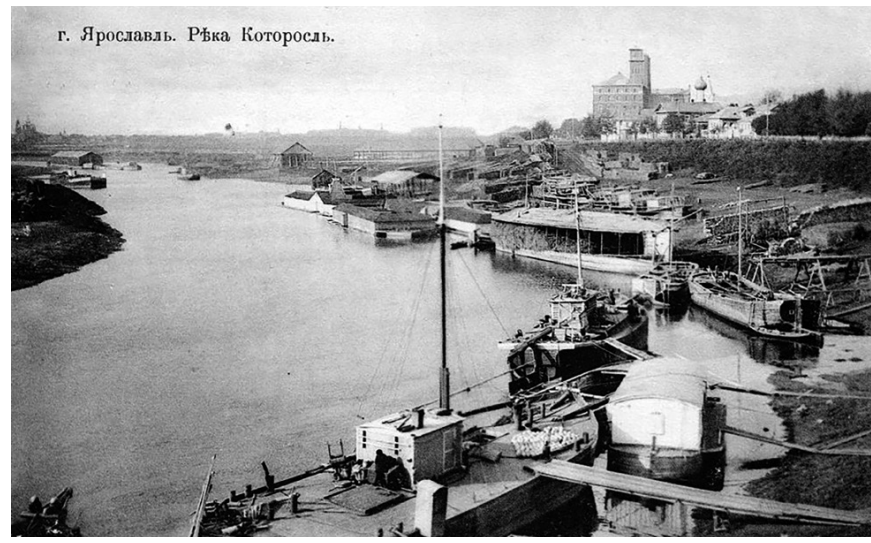

Рис. 4. Река Которосль. Конец ХІХ века

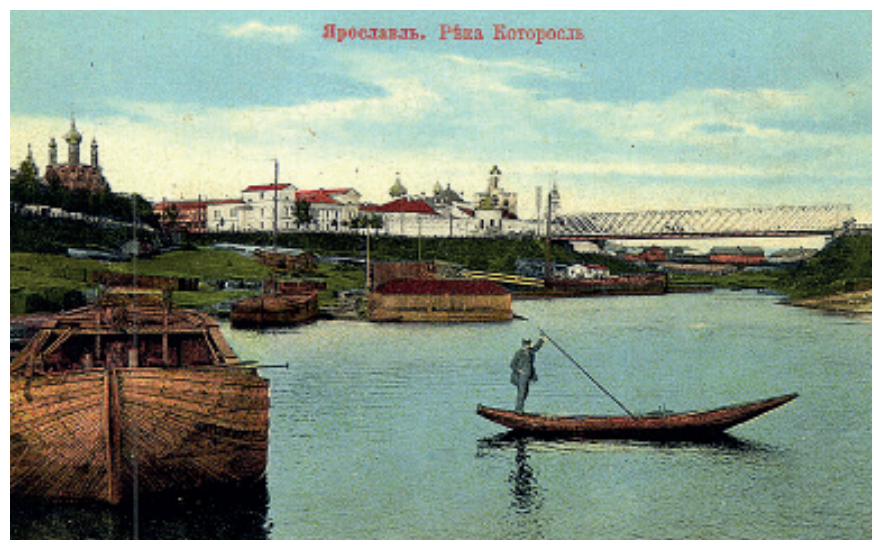

Рис. 5. Мост через реку Которосль. Фото начала ХХ века 
радикально реконструктивный, сколько корректирующий характер. Например, предложение о постройке пожарного депо Вольного пожарного общества на Сенной площади², по прокладке Спасской улицы ${ }^{23}$ или об устройстве на Сенной площади рынка ${ }^{24}$. Необходимость устройства в городе нового рынка диктовалось активным развитием мелкой торговли, не помещавшейся в строениях старого «Мытного двора» в центре города. Интересно, что место нового рынка было специально выбрано неподалёку от железнодорожного узла и станции «Всполье», где предполагалось устроить центральный вокзал Северных железных дорог. Железобетонный корпус рынка ${ }^{25}$ должен был быть возведён напротив здания пожарного депо, построенного за несколько лет до возникновения идеи о превращении Сенной площади в рыночную. Документационные неточности не позволили ТСК утвердить проект до 1914 года, дальнейшей его реализации помешала война.

Перечисленные планировочные изменения, которые вносились в генеральный план города на протяжении второй половины XIX - начала XX века показывают, что сложившаяся градостроительная структура Ярославля не подвергалась серьёзным реконструктивным переменам. В основном коррективы носили местный локальный характер, причём они чаще всего не опережали потребности и не рассчитывались на далёкую перспективу, обслуживая необходимости сегодняшнего дня. Осуществление же перспективных проектов, незаурядным примером которого служит проект зимней гавани, как правило, наталкивалось на экономические препятствия и сиюминутные частнособственнические интересы, шедшие в разрез с интересами города в целом.

Несмотря на важное торговое значение города-порта, промышленное развитие Ярославля нельзя было назвать бурным. Хотя к началу XX века здесь работало 57 промышленных предприятий, большинство их было мелкими производствами - спичечный, лесопильный, кожевенный, войлочный, валеночный, скорняжный, воскобойный и колокололитейный заводы функционировали здесь, имея зачастую не более десяти рабочих. Более крупными были химические заводы и табачная фабрика. Самым крупным предприятием Ярославля была фабрика Товарищества Ярославской Большой мануфактуры, вырабатывавшая бумажную и льняную пряжи. Пятиэтажные корпуса фабрики вносили новые черты в патриархальный силуэт города, насыщенный куполами средневековых храмов. Расположенные на речных берегах эти здания своими простыми кубообразными краснокирпичными объёмами и трубами были своеобразными символами новой прагматической эпохи.

\footnotetext{
2206 изменении части плана г. Ярославля в связи с постройкой пожарного депо на Сенной площади. 1903. // РГИА. Ф. 1293. 0п. 135. Е.х. 55.

${ }^{23} 06$ изменении части плана г. Ярославля в связи с продолжением Спасской улицы. 1900 // РГИА. Ф. 1293. 0п. 132. Е.х. 41.

${ }^{24} 06$ изменении плана Ярославля. 1912-1915 // РГИА. Ф. 1288. 0п. 5. Е.х. 100. ${ }^{25} 06$ изменении плана Ярославля. 1912-1915 // РГИА. Ф. 1288. 0п. 5. Е.х. 100. Л. 16.
}

Относительная промышленная неразвитость Ярославля подчёркивает другую сторону его жизни во второй половине XIX - начале XX века. Город был одним из северных российских центров просвещения и культуры (здесь работало 41 учебное заведение, два театра) и крупным торговым центром. Хотя традиционная ярмарка стеклянной фаянсовой и фарфоровой посуды бывала здесь лишь раз в год, в Ярославле работали отделения всех крупнейших банков страны - Государственного, Крестьянского поземельного, Московского международного, Городского общественного, Московского и Ярославско-Костромского, обслуживавших городское купечество и их разнообразные торговые сделки.

Одной из важнейший и новаторских сторон градостроительства второй половины XIX - начала XX века было неуклонное усовершенствование способов инженерного благоустройства и инженерных сетей, существенно повышавших комфортность городской жизни. С конца 1860-х годов в Ярославле ведётся работа по прокладке водопровода ${ }^{26}$, в конце 1890-х годов начинается электрификация города - сначала зданий ${ }^{27}$, затем улиц, тогда же город оснащается телефонной связью, которую в 1900-х годах уже реконструируют ${ }^{28}$, в 1914-1916 годы создаётся проект канализации ${ }^{29}$.

Вместе с инженерным благоустройством активно развивается общественный транспорт. Одновременно с прокладкой электрокабелей для освещения зданий в 1896 году поднимается вопрос об устройстве в Ярославле электрических железных дорог ${ }^{30}$, подряд на которые получает бельгийское акционерное общество и его инженер Дени ${ }^{31}$. (Бельгийские инженеры и компании прочно утвердились в строительстве

\footnotetext{
${ }^{26} 06$ устройстве водопроводов в Ярославле. 1869-1877 // РГИА. Ф. 1287. 0п. 33. Е.х. 87; Проект водоснабжения Ярославля, 1875 // РГИА. Ф. 1293. Оп. 167. Ярослав. губ. Е.х. 18.

${ }^{27} 06$ устройстве электрического освещения в зданиях Ярославля, 1896 // РГИА. Ф. 1293. 0п. 92. Е.х. 296; 0б устройстве электрического освещения в зданиях Ярославля. 1897-1898 // РГИА. Ф. 1293. 0п. 93. Е.х. 137.

${ }^{28} 0$ переустройстве Ярославской телефонной сети. 1900-1902 // РГИА. Ф. 1289. 0п. 6. Е.х. 78.

${ }^{29} 06$ устройстве канализации в Ярославле. 1914 // РГИА. Ф. 1293. 0п. 110. Е.х. 94; Проект канализации Ярославля. 1915-1916 // РГИА. Ф. 1293. 0п. 167, Яросл. губ. Е.х. 20.
}

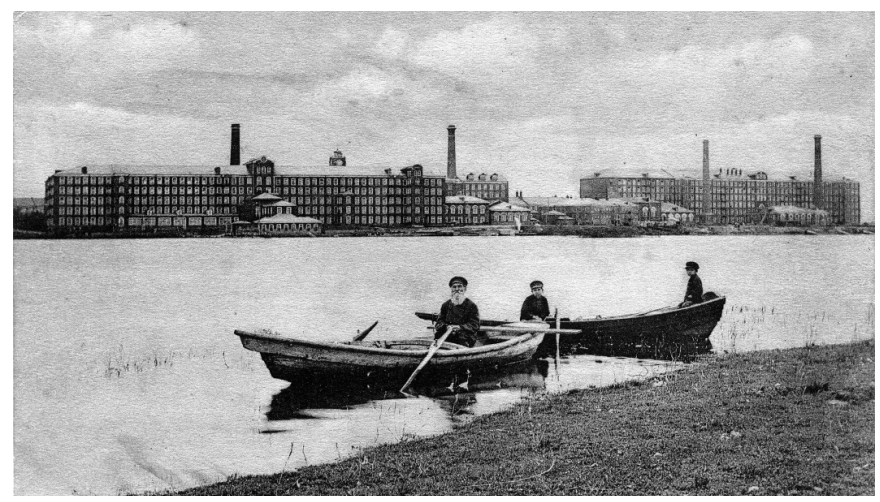

Рис. 6. Фабрика Товарищества Большой Ярославской мануфактуры. Начало XX века 
русских трамвайных и железнодорожных путей: от активного участия как в благоустройстве отдельных городов - например, в Москве конка так и называлась «бельгийской», до таких беспрецедентных строек как прокладка КВЖД - Китайско-Восточной железной дороги.) В самом начале XX века трамвайный маршрут соединяет город с вокзалом Московско-Ярославской железной дороги ${ }^{32}$, с Заречьем ${ }^{33}$. Совокупность этих сведений позволяет сделать вывод, что Ярославль был в числе тех русских городов, которые вслед за столицами Российской империи наиболее быстро реагировали на технические новинки в области городского благоустройства.

Развивалось и общественное озеленение города. На уже упоминавшейся набережной Волги был разбит Некрасовский бульвар, с которого к реке шёл живописный Мякушинский спуск. Кроме него в городе были городской и Казанский бульвары. В центре города был разбит Власьевский сад, а за Романовской заставой - Загородный сад.

Как уже отмечалось, уже в первой половине XIX века сформировалась специфика архитектурного облика Ярославля нового времени, предопределённая контрастным сочетанием средневековых и классицистических построек. Эти тенденции наши своё продолжение и на протяжении второй половины XIX - начала XX века. Если вплоть до конца $1860-\mathrm{x}$ - начала 1870-х годов в городе ещё строились позднеклассицистические здания, в 1880-х - 1890-х им на смену приходит «русский стиль», распространяющийся как в деревянной застройке, так и в каменных домах, декор которых находил также яркие прототипы в Ярославском каменном узорочье XVII века. Наличие специфического местного вкуса сказалось во второй половине XIX - начале XX века и в том, что в зодчестве города довольно значительно распространилось применение многоцветной керамики, также имевшее корни в средневековой местной традиции. Конечно, в городе были примеры и всех остальных стилистических модификаций эклектики, а в начале XX века - модерна, наиболее монументальным сооружением которого была гостиница «Бристоль». Пёстрое стилистическое разнообразие демонстрировали торговая Власьевская улица: двух-трёхэтажная её застройка, выделявшаяся броскими вывесками, куполами, кокошниками, представляла все стили: от деревянного ампира до модерна. Аналогична была стилистическая палитра особняков на Рождественской улице.

Однако представляется неслучайным тот факт, что в Ярославле начала XX века ведущим стилем стал неоклассицизм. Техническое училище на Духовской улице, мужская и Мариинская женская гимназии на Коммерческой улице и торговая школа, женская гимназия А.Д. Антиповой, Семёновский мост, Общество музыкальных и драматических искусств, наконец, новый театр - всё это монументальные неоклассицистические постройки города. Особенно в этом ряду выделяется театр имени Ф.Г. Волкова ${ }^{34}$, архитектурный облик которого ориентированный не просто на язык классических форм, а на формы московского ампира, воплощённого произведениями Д. Джилярди и А. Григорьева, отчётливо показывает традиционную для Ярославля ориентацию на национальное наследие.

Высокая художественная ценность наследия средневекового Ярославля обусловила на протяжении всей второй половины XIX - начала XX века проведение в нём реставрационных работ. В 1857 году реставрировалась Угличская башня ${ }^{35}$, в 1895-1896-м был создан проект ${ }^{36}$, а в 1901-1904 годах проведена реставрация церкви Иоанна Предтечи в Толчкове ${ }^{37}$, в 1896 году реставрирована Богородская башня ${ }^{38}$. Это не только

\footnotetext{
${ }^{30} 06$ устройстве электрических железных дорог в Ярославле. 1896 // РГИА. Ф. 1293. 0п. 92. Е.х. 136; 0б устройстве электрического трамвая в Ярославле. 1898 // РГИА. Ф. 1293. 0п. 94. Е.х. 237.

31 «Ярославские трамваи» - бельгийское акционерское общество. Цели - эксплуатация трамвайной сети, устройство электрического освещения как городского, так и для частных лиц, а также применение энергии в промышленных надобностях. (РГИА. Ф. 1263. 0п. 2. Е.х. 5498); 0 разрешении бельгийскому подданному Дени на устройство и эксплуатацию электрических железных дорог в г. Ярославле. 1896-1914 // РГИА. Ф. 1287. 0п. 43. Е.х. 1442.

320 прокладке линии трамвая в Ярославле по обочине шоссе к вокзалу 1900-1901 // РГИА. Ф. 190. 0п. 4. Кн. 3. Е.х. 5797.

${ }^{33} 0$ прокладке рельсового пути для электрического трамвая по мосту через р. Которосль. 1909 // РГИА. Ф. 190. 0п. 4. Ч. 6. Е.Х. 9661

340 постройке нового каменного театра в Ярославле. 1910 // РГИА. Ф. 1293. 0п. 106. Е.х. 6.

3506 отпуске средств на ремонт древней Угличской башни в Ярославле. 1857 // РГИА. Ф. 1263. 0п. 1. Е.х. 2635. Ст. 1164.
}

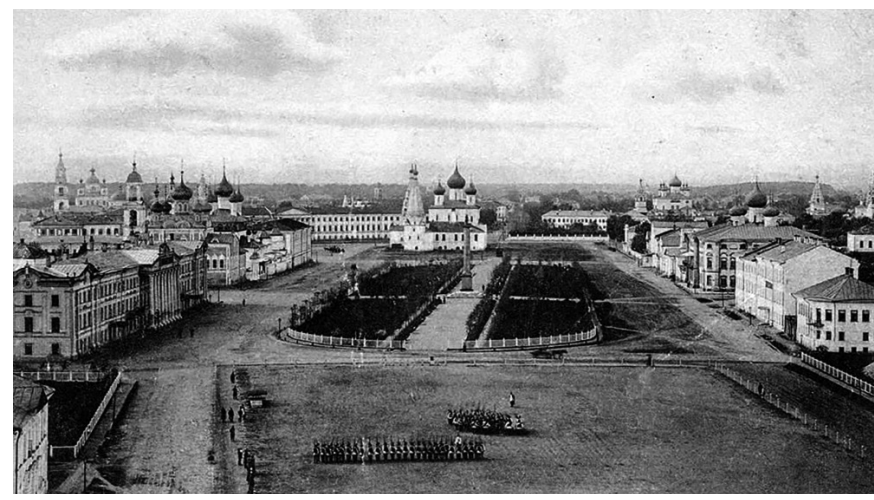

Рис. 7. Ильинская площадь в Ярославле. Начало ХХ века

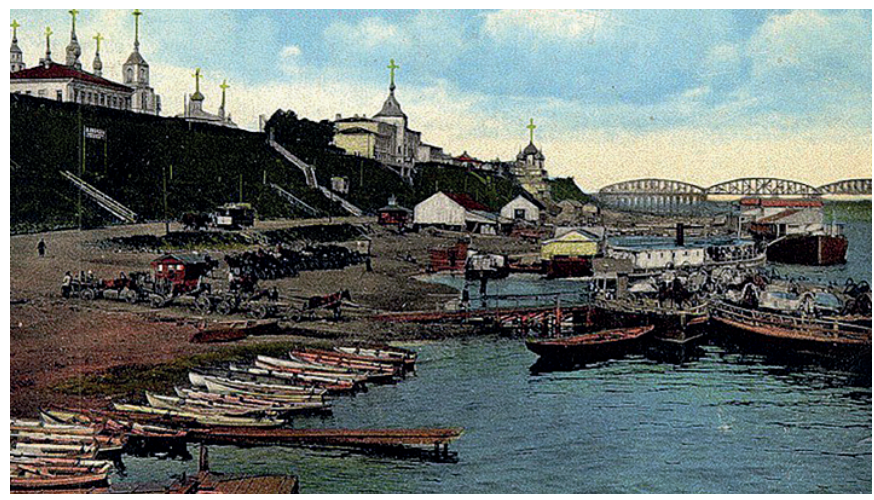

Рис. 8. Набережная Волги в Ярославле. Начало XX века 
способствовало укоренению в жителях уважительного отношения к своей старине, но поднимало культуру строительного дела в целом, в том числе и в храмовом строительстве.

Церковное строительство в городе в рассматриваемый период не было интенсивным, как правило, поновлялись или расширялись уже существовавшие храмы, строились храмы при училищах, например при женском епархиальном ${ }^{39}$, созданный по проекту Фёдора Солнцева - знаковой фигуры в развитии русского стиля. К древним церквям пристраивались колокольни ${ }^{40}$, появилась часовня св. Александра Невского ${ }^{41}$. Пожалуй, наиболее заметным стало строительство иноверческих храмов. Как и большинство крупных торговых городов России, Ярославль во второй половине XIX - начале XX века был многонациональным городом. Здесь проживало около 1000 римских католиков, среди которых были поляки, литовцы, итальянцы; более 1000 евреев; более 300 немцев, несколько сотен мусульман и т.д. Поэтому, кроме православных храмов (их было 75) в городе действовали единоверческая, католическая и лютеранская церкви, синагога. В середине XIX века началось строительство Успенской единоверческой

\footnotetext{
${ }^{36} 0$ назначении делегата от Синода в Архитектурную комиссию по рассмотрению проекта реставрации древней церкви Иоанна Предтечи в Толчковской слободе в г. Ярославле. 1895-1896 // РГИА. Ф. 799. 0п. 17. Е.х. 72.

${ }^{37} 0$ реставрации ц.Иоанна Предтечи в Толковее. 1901-1904 // РГИА. Ф. 799. 0п. 25. Е.х. 889.

${ }^{38} 0$ реставрации Богородской башни в г. Ярославле. 1896 // РГИА. Ф. 1293. 0п. 92. Е.х. 147.

39 Проект церкви при женском епархиальном училище. 1858-1861. Арх. Ф.Солнцев, Н.Попов // РГИА. Ф. 835. Оп. 1. Е.х. 1025.

${ }^{40} 0$ постройке колокольни при Власьевской церкви в Ярославле. 1860-1864 // РГИА. Ф. 797. Оп. 30.2 отд. 2 ст. Е.х. 68.

${ }^{41} 0$ постройке каменной часовни в Ярославле. 1889 // РГИА. Ф. 1293. 0п. 122. Е.х. 29.

4206 отводе места под постройку Успенской единоверческой церкви в Толчковской слободе в Ярославле. 1857 // РГИА. Ф. 797. Оп. 27. Отд. 2. Ст. 1. Е.х. 77. 430 построении в Ярославле римско-католического костёла. 1874 // РГИА. Ф. 797. 0п. 44. ІІ отд. 3 ст. Е.х. 252.

440 разрешении производить сбор средств для построения мечети в Ярославле. 1906-1908 // РГИА. Ф. 821. 0п. 8. Е.х. 716. Магом. отд.
}

церкви в Толчковской слободе $\mathrm{e}^{42}$, в 1870-1880-х годах также за рекой Которослью строился католический костёл ${ }^{43}$, в начале XX века магометанская община Ярославля начала сбор средств для возведения мечети ${ }^{44}$.

Однако очевидно, что эти немногочисленные постройки не могли существенно повлиять на облик города, панорама которого в основном сохраняла силуэт, сложившийся ещё в начале XIX века, а застройка - планировочную структуру того времени. Такой последовательный традиционализм в области архитектурного образа и стилистики в сочетании с последовательным внедрением в городское благоустройство технических новаций, развитием железнодорожного строительства и портового хозяйства - отличительная черта градостроительного развития Ярославля второй половины XIX - начала XX века.

\section{Лuтература}

1. Градостроительство России середины XIX - начала XX века. Кн. 3 / Под ред. Е.И. Кириченко. - М., Прогресс-Традиция, 2010.

2. Гуляницкий, Н.Ф. Города Верхнего Поволжья и Севера / Н.Ф. Гуляницкий // Русское градостроительное искусство. Москва и сложившиеся русские города / Под ред. Н.Ф. Гуляницкого. T. IV. - М.: Стройиздат, 1998.

3. Проект гавани в г. Ярославле на р. Которосли. Сост. Инж. П.П. Чубинским. 1898-1899. - Ярославль, 1899.

\section{Literatura}

1. Gradostroitel'stvo Rossii serediny XIX - nachala XX veka. Kn. 3 / Pod red. E.I. Kirichenko. - M., Progress-Traditsiya, 2010.

2. Gulyanitskij N.F. Goroda Verhnego Povolzh'ya i Severa / N.F. Gulyanitskij // Russkoe gradostroitel'noe iskusstvo. Moskva i slozhivshiesya russkie goroda / Pod red. N.F. Gulyanitskogo. T.IV. - M.: Strojizdat,1998.

3. Proekt gavani v g. Yaroslavle na r. Kotorosli. Sost. Inzh. P.P. Chubinskim. 1898-1899. - Yaroslavl', 1899.

Мария Владимировна Нащокина (Москва). Доктор искусствоведения, академик РААСН. Научный сотрудник, заведующая отделом филиала ФГБУ «ЦНИИП Минстроя России» Научно-исследовательского института теории и истории архитектуры и градостроительства (111024, Москва, Душинская ул., 9. НИИТИАГ). Сфера научных интересов: русская архитектура и искусство Нового времени; проблемы сохранения архитектурного наследия. Автор более 350 публикаций, в том числе 47 книг. Тел: +7 (916) 560-92-01. E-mail: n_maria53@mail.ru.

Maria Vladimirovna Nashchokina (Moscow). Doctor of Art, Academician of RAACS. Research associate, head of Department of the Scientific Research Institute of Theory and History of Architecture and Urban Planning (branch of the Central Institute for Research and Design of the Ministry of Construction, Housing and Utilities of Russia) (111024, Moscow, Dushinskaya st, 9. NIITIAG). Research interests: Russian architecture and art of the new time; problems of architectural heritage conservation. The author of more than 350 publications, including 47 books. Tel.: +7 (916) 560-92-01. E-mail: n_maria53@mail.ru. 